\title{
Mediterranean agro-industrial wastes as valuable substrates for lignocellulolytic enzymes and protein production by solid-state fermentation
}

\author{
Daniel Sousa, Armando Venâncio, Isabel Belo $\odot$ and José M Salgado*๑
}

\begin{abstract}
BACKGROUND: Mediterranean agro-food industries (such as wineries, breweries and olive mills) dispose of great amounts of waste. This generates environmental problems, and the waste has a low nutritional value for use as animal feed. In this sense, solid-state fermentation (SSF) can increase the nutritional value of these wastes and simultaneously produce lignocellulolytic enzymes.

RESULTS: All fermented wastes were enriched in protein by the three fungi studied. Aspergillus ibericus was the fungus with the biggest increase of protein, which ranged from 1.4 times to 6.2 times with respect to unfermented wastes. Likewise, $A$. ibericus achieved the maximum cellulase and xylanase activities. The relationships among substrates composition, fungi used and SSF performance were evaluated by principal components analysis. The high content of cellulose and hemicellulose favoured lignocellulolytic enzymes production, and the phenolics content was negatively correlated with enzymes production and with the increase of protein by SSF. Furthermore, the scanning electron microscopy analysis showed the growth of fungi over solid wastes, the formation of conidiophores and the changes in their structures.
\end{abstract}

CONCLUSION: The nutritional value of Mediterranean wastes was improved and other value-added products such as lignocellulolytic enzymes were produced in the same process, which could facilitate the efficient reuse of these wastes. (c) 2018 Society of Chemical Industry

Keywords: Mediterranean wastes; solid-state fermentation; lignocellulolytic enzymes; scanning electron microscopy

\section{INTRODUCTION}

Presently, there is a growing interest in the exploitation of wastes generated by the food industry. This is key to a circular economy, which is an alternative to a traditional linear economy, and it searches to use the resources for as long as possible, to extract the maximum value from them, and then to recover and reuse the wastes. Agro-food industries from the Mediterranean region are dominated by production of olive oil and wine. According to the Food and Agriculture Organization Corporate Statistical Database (FAOSTAT), in 2014 the production of virgin olive oil and wine was $93 \%$ and $51 \%$ of world production respectively. In terms of quantity in tonnes, beer from barley is the third processed crop in the Mediterranean region (FAOSTAT, 2014). The three products sum to about $27 \times 10^{6} \mathrm{t}$ in the Mediterranean region, which can generate in their production about $9 \times 10^{6} \mathrm{t}$ of solid wastes each year. Thus, to search for applications for these wastes that are more profitable and environmentally friendly must be a permanent priority.

In this sense, the utilization of agro-food wastes has been proposed for animal feed. Wastes utilization as an alternative source for animal feed needs huge attention because their recycling and reduction are good ways to minimize environmental pollution and improve the present living conditions. ${ }^{1}$ Currently, 33\% of croplands are used for livestock feed production, which is a key factor in deforestation. By using agro-industrial wastes as animal feed, food supply can increase and reduce the environmental impact of these wastes. In addition, the price of cereals has increased in recent years, and so alternative sources of feedstuffs should be considered in order to reduce production costs. ${ }^{2}$ However, the nutritional quality of these wastes does not meet the standards that are required for animal feed, mainly due to low protein content. In this sense, olive mills and wineries wastes such as olive pomace, grape marc and vine-shoot trimmings (VST) are noted for their low nitrogen $(\mathrm{N})$ content of between 0.6 and $1.7 \%$ of dry solids. ${ }^{3}$ On the other hand, brewers' spent grain (BSG) has a higher $\mathrm{N}$ content. ${ }^{4}$ The mixture of wastes and the application of biotechnology processes such as solid-state fermentation (SSF) can enrich them for use directly in animal feeds. ${ }^{5}$ SSF is considered an alternative technology to obtain new products and use wastes as cheap raw material. ${ }^{6}$

In recent years there has been further focus on improving the protein content of lignocellulosic wastes by SSF. ${ }^{1}$ Bioprocessing of

\footnotetext{
Correspondence to: JM Salgado, Centre of Biological Engineering, University of Minho, Campus de Gualtar, Braga 4710-057, Portugal. E-mail:jmsalgado@ceb.uminho.pt
}

Centre of Biological Engineering, University of Minho, Braga, Portugal 
wastes by SSF is a low-cost technique to obtain nutritive animal feed. ${ }^{7}$ Several workers have demonstrated the protein enhancement of agro-food wastes by fungi of around $5-26 \% .{ }^{8-10}$ On the other hand, lignocellulosic wastes are considered as being of low digestibility, ${ }^{11}$ but SSF by fungi can improve the digestibility by enzymes production, since these can break the bonds of hemicellulose and cellulose with the lignin. In addition, the SSF of lignocellulosic materials can increase the degradability of dietary protein in the rumen. ${ }^{12}$ Thus, several nutritional aspects of agro-food wastes can be improved in the same biotechnology process, increasing the value of wastes.

Fungi comply with several of these aspects as they have high protein content, are safe for human and animals and have the ability to grow in agro-industrial wastes. ${ }^{10}$ Aspergillus niger is a filamentous fungus considered as generally regarded as safe by the US Food and Drug Administration. Aspergillus ibericus and Aspergillus uvarum are species isolates from grapes unable produce mycotoxins. ${ }^{13}$ Their ability to colonize agro-industrial wastes has been demonstrated. ${ }^{3}$ However, the potentiality of $A$. ibericus and A. uvarum to increase protein content of agro-industrial wastes was barely studied.

This study was aimed to increase of nutritional value of winery, brewery and olive mill wastes and produce lignocellulolytic enzymes simultaneously. Three fungi were tested in four different wastes. The effect of fungi growth on lignocellulose composition and phenolic compounds was evaluated. In addition, the relationship between substrate composition, fungi used and the results of SSF was studied. Finally, the structure of unfermented and fermented solid wastes was analysed by scanning electron microscopy (SEM) to show the changes produced by fungi.

\section{EXPERIMENTAL}

\section{Agro-industrial wastes}

During this work, four wastes were used: Brewers' spent grain (BSG) obtained from the brewery industry after mixing hot water and malt, exhausted olive pomace (EOP) collected from the olive oil industry after recovery of residual olive oil from crude olive pomace, exhausted grape mark (EGM) and vine-shoots trimming (VST) from the winery industry after distilling of the residual alcohol and after the pruning respectively. These residues were all obtained from industries in the north of Portugal during season 2015-2016. The wastes were dried at $65^{\circ} \mathrm{C}$ for $24 \mathrm{~h}$ and stored at room temperature.

\section{Fungi}

Three species of Aspergillus from MUM (Braga, Portugal) were used: A. niger 01UAs181, A. uvarum MUM08.01 and A.ibericus MUM03.49. The fungi were cultivated on malt extract agar $\left(20 \mathrm{~g} \mathrm{~L}^{-1}\right.$ malt extract, $1 \mathrm{~g} \mathrm{~L}^{-1}$ peptone, $20 \mathrm{~g} \mathrm{~L}^{-1}$ glucose and $20 \mathrm{~g} \mathrm{~L}^{-1}$ agar) slants and incubated at $25^{\circ} \mathrm{C}$ for 6 days. Strains were preserved at $4^{\circ} \mathrm{C}$ and cultured monthly on fresh malt extract agar slants.

\section{SSF of agro-food wastes}

BSG, EOP, EGP and VST were used as substrate in SSF experiments to evaluate the three fungi $A$. uvarum, A. niger and A. ibericus. The SSF process was carried out in $500 \mathrm{~mL}$ Erlenmeyer flasks with $10 \mathrm{~g}$ of dry substrate. Moisture level was adjusted to $75 \%$ (wet basis); this moisture was optimized in previous work. ${ }^{14}$ The ratio carbon (C)/N was fixed to 15 (value of BSG) for comparison of the substrates. Different concentrations of urea were added to EOP,
EGP and VST to achieve a C/N ratio of 15 . Erlenmeyer flasks with solid medium were sterilized at $121^{\circ} \mathrm{C}$ for $15 \mathrm{~min}$. For inoculation, the fungi were suspended in a sterile solution $\left(1 \mathrm{~g} \mathrm{~L}^{-1}\right.$ peptone and $0.1 \mathrm{~g} \mathrm{~L}^{-1}$ Tween 80 ). The inoculum spore concentration was adjusted to $10^{6}$ spores $\mathrm{mL}^{-1}$ using a Neubauer counting chamber. Each Erlenmeyer flask was inoculated with $2 \mathrm{~mL}$ of spore suspension and incubated at $30^{\circ} \mathrm{C}$ for 6 days. A control experiment was performed for each sterilized waste without fungi inoculation.

\section{Extraction of enzymes after SSF}

At the end of each experiment, a representative sample $(5 \mathrm{~g}$ dry substrate) was used to extract enzymes with a solution of $10 \mathrm{~g} \mathrm{~L}^{-1}$ sodium chloride and $5 \mathrm{~g} \mathrm{~L}^{-1}$ Triton X-100, ratio liquid : solid of 5 , at room temperature with mechanical agitation for $1 \mathrm{~h}$. This solution was optimized in previous studies (data not shown). Triton X-100 is a non-ionic surfactant, and it can improve the solubilization of the enzyme from the solid substrate to the solution. Sodium chloride was used to increase the stability of the enzyme, based on literature. ${ }^{15}$ Subsequently, the extract was filtered through a nylon net and the liquid fraction was centrifuged at $6000 \times g$ for $10 \mathrm{~min}$. The enzyme extract was recovered and stored at $-20^{\circ} \mathrm{C}$ until its analysis. A representative sample of fermented solid $(5 \mathrm{~g}$ of dry substrate) was removed before enzyme extraction; the solid was dried at $50^{\circ} \mathrm{C}$ for $48 \mathrm{~h}$ and characterized.

\section{Analysis of enzyme activities}

The activity of cellulases (endo-1,4- $\beta$-glucanase) was determined with the Azo-CM-Cellulose S-ACMCL (Megazyme International, Ireland) enzymatic kit. Enzymatic extracts were diluted with $0.1 \mathrm{~mol} \mathrm{~L}^{-1}$ sodium acetate buffer $(\mathrm{pH} 4.6)$ to a final volume of $0.5 \mathrm{~mL}$ and mixed with $0.5 \mathrm{~mL}$ substrate solution (CM-Cellulose $\left.4 \mathrm{~mol} \mathrm{~L}^{-1}\right)$. Before analysis, the solutions were pre-equilibrated at $40^{\circ} \mathrm{C}$. A blank was performed with water and substrate solution. Then, the mixture was stirred and incubated for $40^{\circ} \mathrm{C}$ and $10 \mathrm{~min}$. To end the reaction, substrate was precipitated by the addition of $2.5 \mathrm{~mL}$ of precipitant solution $\left(40 \mathrm{~g} \mathrm{~L}^{-1} \mathrm{C}_{2} \mathrm{H}_{3} \mathrm{NaO}_{2} \cdot 3 \mathrm{H}_{2} \mathrm{O}, 4 \mathrm{~g} \mathrm{~L}^{-1}\right.$ $\mathrm{Zn}\left(\mathrm{O}_{2} \mathrm{CCH}_{3}\right)_{2}$ in ethanol solution at $\left.76 \%, \mathrm{pH} 5\right)$ with vigorous stirring for $10 \mathrm{~s}$ on a vortex mixer. The reaction tubes were stabilized $10 \mathrm{~min}$ at room temperature. The tubes were stirred again and centrifuged at $1000 \times g$ for $10 \mathrm{~min}$. The supernatant solution absorbance was measured at $590 \mathrm{~nm}$ and the enzyme activity was determined by reference to a standard curve performed with A. niger endo-cellulase. One unit of enzyme activity was defined as the amount of enzyme required to release $1 \mu \mathrm{mol}$ of glucose reducing sugar equivalents from carboxymethyl cellulose in $1 \mathrm{~min}$ at $40^{\circ} \mathrm{C}$ and $\mathrm{pH}$ 4.6. The values of cellulases activity are expressed in units per gram of dry substrate $\left(\mathrm{U} \mathrm{g}^{-1}\right)$.

The analysis of endo-1,4- $\beta$-xylanase was carried out using azo-wheat arabinoxylan S-AWAXP (Megazyme International, Ireland) as substrate. The procedure was performed in the same way as cellulases activity analysis (as already described), except the buffer solution was $0.1 \mathrm{~mol} \mathrm{~L}^{-1}$ sodium acetate $(\mathrm{pH} 4.5)$, the precipitation solution was ethanol $(95 \% \mathrm{v} / \mathrm{v})$ and centrifugation was performed at $1500 \times g$. The supernatant solution absorbance was measured at $590 \mathrm{~nm}$ and the enzyme activity was determined by reference to a standard curve performed with A. niger endo-xylanase. One unit of enzyme activity was defined as the amount of enzyme required to release $1 \mu \mathrm{mol}$ of xylose reducing sugar equivalents from wheat arabinoxylan in $1 \mathrm{~min}$ at $40^{\circ} \mathrm{C}$ and $\mathrm{pH}$ 4.5. The values of xylanases activity were expressed in units per gram of dry substrate $\left(\mathrm{U} \mathrm{g}^{-1}\right)$. 
Table 1. Composition of agro-food wastes

\begin{tabular}{|c|c|c|c|c|}
\hline Parameter & EGM & EOPb & VST & BSG \\
\hline Humidity $\left(\mathrm{g} \mathrm{kg}^{-1}\right)$ & $109 \pm 1$ & $96.6 \pm 1.2$ & $63.3 \pm 5.3$ & $735 \pm 4$ \\
\hline Total solids $\left(\mathrm{g} \mathrm{kg}^{-1}\right)$ & $891 \pm 1$ & $903.4 \pm 1.2$ & $936.7 \pm 1$ & $265 \pm 4$ \\
\hline Ash $\left(\mathrm{g} \mathrm{kg}^{-1}\right)$ & $90.95 \pm 5.58$ & $33.6 \pm 1.68$ & $35.87 \pm 4.32$ & $12.75 \pm 0.05$ \\
\hline Lignin $\left(\mathrm{g} \mathrm{kg}^{-1}\right)$ & $666.26 \pm 5.09$ & $550 \pm 15$ & $340.85 \pm 5.54$ & $153.68 \pm 17.58$ \\
\hline Hemicellulose $\left(\mathrm{g} \mathrm{kg}^{-1}\right)$ & $101.78 \pm 3.81$ & $289.16 \pm 0.54$ & $237.79 \pm 3.81$ & $339.96 \pm 5.05$ \\
\hline Cellulose $\left(\mathrm{g} \mathrm{kg}^{-1}\right)$ & $144.49 \pm 2.11$ & $128.77 \pm 2.42$ & $423.96 \pm 5.25$ & $362.16 \pm 10.24$ \\
\hline Crude protein $\left(\mathrm{g} \mathrm{kg}^{-1}\right)$ & $134.74 \pm 3.97$ & $57.51 \pm 3.58$ & $37.9 \pm 0.2$ & $217 \pm 21$ \\
\hline Soluble protein ${ }^{\mathrm{a}}\left(\mathrm{g} \mathrm{kg}^{-1}\right)$ & $0.54 \pm 0.08$ & $0.54 \pm 0.08$ & $0.54 \pm 0.08$ & $1.07 \pm 0.33$ \\
\hline Reducing sugars ${ }^{\mathrm{a}}\left(\mathrm{g} \mathrm{kg}^{-1}\right)$ & $4.1 \pm 0.07$ & $33.07 \pm 1.59$ & $4.1 \pm 0.07$ & $132.53 \pm 0.41$ \\
\hline Phenols ${ }^{\mathrm{a}}\left(\mathrm{g} \mathrm{kg}^{-1}\right)$ & $1.72 \pm 0.01$ & $7.07 \pm 0.07$ & $1.72 \pm 0.01$ & $2.39 \pm 0.04$ \\
\hline $\mathrm{N}\left(\mathrm{g} \mathrm{kg}^{-1}\right)$ & $21.56 \pm 0.64$ & $9.2 \pm 0.57$ & $6.06 \pm 0.03$ & $34.67 \pm 3.36$ \\
\hline$C\left(\mathrm{~g} \mathrm{~kg}^{-1}\right)$ & $482.4 \pm 16.1$ & $460.7 \pm 12.9$ & $462.6 \pm 2.2$ & $471.4 \pm 0.01$ \\
\hline $\mathrm{C} / \mathrm{N}$ & 22.38 & 50.1 & 74.85 & 12.23 \\
\hline Calcium $\left(\mathrm{g} \mathrm{kg}^{-1}\right)$ & $3.04 \pm 0.19$ & $1.8 \pm 0.2$ & $2.02 \pm 0.12$ & $2.45 \pm 0.06$ \\
\hline Potassium $\left(\mathrm{g} \mathrm{kg}^{-1}\right)$ & $7.14 \pm 0.22$ & $14.2 \pm 0.7$ & $4.76 \pm 0.15$ & $0.72 \pm 0.04$ \\
\hline Magnesium ( $\mathrm{g} \mathrm{kg}^{-1}$ ) & $0.14 \pm 0.01$ & $0.47 \pm 0.01$ & $0.09 \pm 0.01$ & $1.81 \pm 0.06$ \\
\hline Zinc $\left(\mathrm{mg} \mathrm{kg}^{-1}\right)$ & $9 \pm 2.55$ & $10.5 \pm 0.7$ & $6 \pm 1.7$ & $154 \pm 4.24$ \\
\hline Copper $\left(\mathrm{mg} \mathrm{kg}^{-1}\right)$ & $50.1 \pm 8.9$ & $11 \pm 1$ & $33.4 \pm 5.9$ & $12.5 \pm 0.7$ \\
\hline Iron $\left(\mathrm{mg} \mathrm{kg}^{-1}\right)$ & $1255.5 \pm 69.16$ & $147 \pm 33$ & $817 \pm 46$ & $138.5 \pm 4.95$ \\
\hline Manganese $\left(\mathrm{mg} \mathrm{kg}^{-1}\right)$ & $43.44 \pm 4.16$ & $10.2 \pm 0.4$ & $28.96 \pm 2.77$ & $40.5 \pm 0.71$ \\
\hline Chromium (mg kg-1) & $47.4 \pm 3.82$ & $<22$ & $31.6 \pm 1.7$ & $<22$ \\
\hline Nickel $\left(\mathrm{mg} \mathrm{kg}^{-1}\right)$ & $45.9 \pm 3.8$ & $<22$ & $30.6 \pm 2.55$ & $<22$ \\
\hline Lead $\left(\mathrm{mg} \mathrm{kg}^{-1}\right)$ & $<22$ & $<22$ & $<22$ & $<22$ \\
\hline Sodium $\left(\mathrm{mg} \mathrm{kg}^{-1}\right)$ & $6110.1 \pm 485.78$ & $92 \pm 5$ & $4073.4 \pm 323.85$ & $56 \pm 1.4$ \\
\hline
\end{tabular}

All values are expressed per kilogram of dry material; BSG, brewers' spent grain; EGM, exhausted grape marc; EOP, exhausted olive pomace; VST, vine-shoot trimmings.

a Value in aqueous extract.

${ }^{\mathrm{b}} \mathrm{C}$ and minerals data were published in Leite et al. ${ }^{19}$

\section{Chemical analysis of unfermented and fermented wastes}

The unfermented and fermented wastes were characterized to observe the effect of fungal growth on their composition. To estimate free sugars, free protein and phenolic compounds in wastes, an extraction with distilled water with liquid: solid ratio of 5 was performed. Free reducing sugars were analysed by the 3,5-dinitrosalicylic acid method. ${ }^{16}$ Proteins were measured by the Bradford method. Total phenols were determined by the Folin-Ciocalteu method (Commission Regulation (EEC) No. 2676/90). N content was analysed by the Kjedahl method. ${ }^{17}$ The crude protein content was calculated on the basis of $\mathrm{N}$ determined by the Kjeldhal method with an appropriate factor of $6.25 .{ }^{18}$ Determinations of cellulose, hemicelluloses, lignin, $\mathrm{C}$ and minerals were carried out following the methods described by Leite et al. ${ }^{19}$ Ashes were determined by high temperature treatment at $575^{\circ} \mathrm{C}$ for $2 \mathrm{~h}$ in a muffle furnace. $\mathrm{C}$ and minerals were analysed following the process described by Salgado and co-workers ${ }^{19}$ Table 1 shows the initial composition of solid wastes.

\section{SEM}

The unfermented and fermented wastes were characterized using a desktop scanning electron microscope coupled with energy-dispersive X-ray spectroscopy (EDS) analysis (Phenom ProX with EDS detector (Phenom-World BV, Netherlands)). All results were acquired using the ProSuite software. The samples were added to aluminium pin stubs with electrically conductive $C$ adhesive tape (PELCO Tabs ${ }^{\mathrm{TM}}$ ), with the excess removed using compressed air. Samples were imaged without coating. The aluminium pin stub was then placed inside a Phenom charge reduction sample holder.

\section{RESULTS AND DISCUSSION}

The main wastes from breweries, wineries and olive mills (BSG, EOP, EGM and VST) were inoculated with three different filamentous fungi: A. uvarum MUM 08.01, A. ibericus MUM 03.49 and A. niger 01UAs183. The goal was the selection of fungus that produces higher cellulose and xylanase activities and increases the protein content of agro-industrial wastes. In previous work, ${ }^{19}$ these strains showed potential for producing lignocellulolytic enzymes on agar plates. In addition, A. uvarum MUM 08.01 showed good results in the increase of protein of agro-food wastes mixtures. ${ }^{20}$

\section{Increasing the protein content of agro-food wastes}

Fungal biomass protein, also known as single-cell protein, is a suitable product to be used as animal feed. It is estimated that the protein content in $A$. niger is $270 \mathrm{~g} \mathrm{~kg}^{-1}$ with balanced essential amino acids. ${ }^{21,22}$ Thus, Aspergillus strains were tested on agro-food wastes to increase their nutritional value.

The protein content was determined in solid substrates before fermentation, in control (solid substrate after addition of urea and sterilization) and in fermented solids. As can be observed in Fig. 1, the protein content of the four fermented wastes was increased with respect to initial waste and control.

BSG was the waste with a higher initial protein content; however, the protein content in other wastes was very low, particularly 


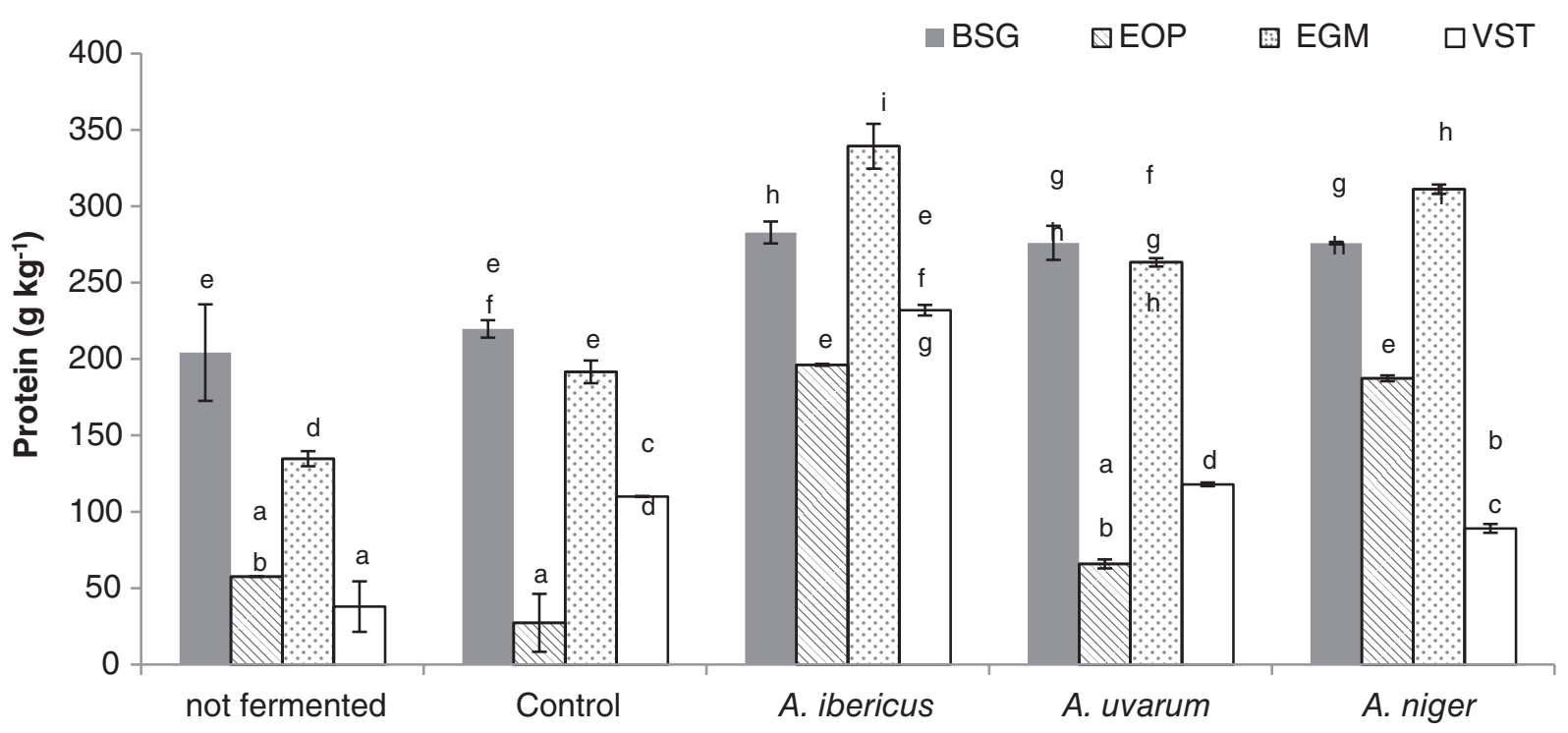

Figure 1. Protein content of the initial substrate, control (solid after sterilization) and residues after SSF with A. ibericus, A. uvarum and A. niger. Letters above each bar indicate the results of Tukey's test $(P<0.05)$; values with shared letters in the same graph are not significantly different. BSG, brewers' spent grain; EOP, exhausted olive pomace; EGM, exhausted grape marc; VST, vine-shoot trimmings.

in EOP $\left(57.5 \mathrm{~g} \mathrm{~kg}^{-1}\right)$ and VST $\left(37.9 \mathrm{~g} \mathrm{~kg}^{-1}\right)$. To observe the effect of heat treatment and the addition of urea, control assays were carried out with each waste. Owing to the protein being measured by Kjehldahl $\mathrm{N}$ method, the addition of urea (source of $\mathrm{N}$ ) could increase the value of $\mathrm{N}$. In addition, the heat treatment of sterilization can hydrolyse or degrade compounds of solid wastes and modify their protein content. However, the addition of urea and the sterilization process (control) barely modified the protein content; only in winery wastes were significant differences observed, where the protein content increased.

Although BSG had a significant protein content, the fermentation with three fungi increased the protein further. There were no significant differences between the three fungi; the increase of protein by SSF of $A$. ibericus was $38.5 \%$. This value was slightly higher than that Canedo et al. ${ }^{23}$ achieved in BSG fermented by Rhizopus oligosporus, in which the protein content was increased by $31.5 \%$ after SSF.

In the same way, the protein was increased in EOP after SSF. The increase was higher than fermented BSG; the fungi that achieved a maximum increase were $A$. ibericus and $A$. niger, with the protein content increasing by 3.4 and 3.2 times respectively. The SSF allowed the protein to increase to similar values of initial BSG, which is considered a nutritional waste to be used as animal feed. Brozzoli et $a .^{24}$ studied the increase of protein in stoned olive pomace by Pleurotus species. In this case, the olive pomace was mixed with other conventional feedstuffs, such as wheat bran, barley grans, and so on. In the best conditions, the protein was increased 1.3 times.

SSF of EGM also showed a protein increase, and $A$. ibericus and $A$. niger were also the fungi that further increased the protein content; $A$. ibericus achieved $340 \mathrm{~g} \mathrm{~kg}^{-1}$ of protein, although no significant differences were observed with $A$. niger. The bioconversion of EGM to nutrient-rich feed was studied by Jin et al., ${ }^{10}$ who enhanced the protein content up to $260 \mathrm{~g} \mathrm{~kg}^{-1}$ after SSF.

Among all wastes, the higher increase of protein was observed using VST as substrate; SSF by A.ibericus increased the protein content 6.1 times with respect to unfermented VST. Thus, SSF was a suitable process to increase the nutritional value of wastes with low protein content. All fungi increased the protein content; however, A. ibericus MUM 03.49 showed the maximum increase in each waste studied. The fungal biomass protein is considered a good source of dietary protein for the feeding of ruminants and improves animal performance. ${ }^{12}$ In the same way, the fungal biomass protein was successfully tested in fish diets. ${ }^{25}$

\section{Production of lignocellulolytic enzymes}

Using the same processes, the production of lignocellulolytic enzymes was evaluated. Figure 2 shows the activities of cellulases and xylanases achieved after SSF. A. ibericus was the fungus that contributed to a higher cellulose activity using BSG as solid substrate. The high content of cellulose and hemicelluloses in BSG induced lignocellulolytic production. The use of BSG as solid substrate has barely been studied, though $\mathrm{Sim}$ and $\mathrm{Oh}^{26}$ evaluated BSG as a solid substrate for cellulose production using the typical cellulases producer Trichoderma reesei and they achieved a $43 \mathrm{U} \mathrm{g}^{-1}$ BSG.

A. niger was the fungus which produced cellulases with higher activity in EGM and VST. In the case of EOP, there were no statistically significant differences $(P<0.05)$ in cellulases activity between $A$. ibericus and $A$. niger. However, no cellulase activity was detected in fermented BSG by $A$. niger.

On the other hand, the maximum xylanase activity was achieved by $A$. ibericus and A. uvarum using BSG as solid substrate, but no significant differences $(P<0.05)$ were observed among them. The production of xylanases and cellulases by $A$. uvarum was less compared with other strains; however, this strain increased the protein content of agro-food wastes. Thus, it is possible that fungi focus their metabolism on biomass growth.

The use of EOP as solid substrate for cellulose and xylanase production was evaluated by Leite et al. ${ }^{19}$ They observed a maximum enzyme production using A. niger CECT 2915, achieving about $25 \mathrm{U} \mathrm{g}^{-1}$ and $35 \mathrm{U} \mathrm{g}^{-1}$ of xylanase and cellulose respectively. Salgado et al. ${ }^{20}$ evaluated the mixture of EGM and crude olive pomace as solid substrate and they achieved $32 \mathrm{U} \mathrm{g}^{-1}$ of cellulose activity and $10.5 \mathrm{U} \mathrm{g}^{-1}$ of xylanase activity using A. uvarum as fungus. 

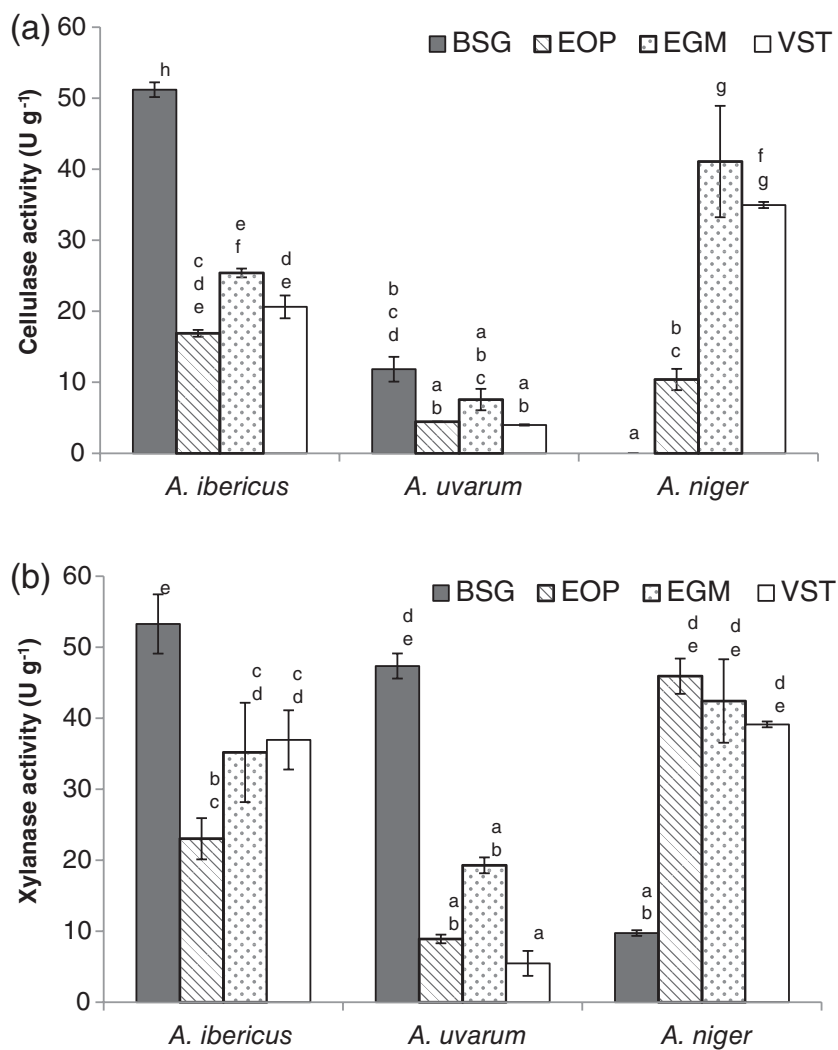

Figure 2. Cellulases (a) and xylanases (b) production during SSF. These results represent the average of two independent experiments, and error bars represent standard deviation. Letters above each bar indicate the results of Tukey's test $(P<0.05)$; values with shared letters in the same graph are not significantly different. BSG, brewers' spent grain; EOP, exhausted olive pomace; EGM, exhausted grape marc ; VST, vine-shoot trimmings.

All wastes showed that they are suitable substrates for cellulose and xylanase production. These agro-food wastes are of a lignocellulosic nature; thus, they can induce the production of lignocellulolytic enzymes. ${ }^{27}$

\section{Effect of fungi on lignocellulosic composition of agro-food wastes}

The lignocellulosic composition of the different wastes was evaluated after SSF with the different fungi in order to determine the reduction of cellulose, hemicellulose, and lignin content.

Figure 3 shows the lignocellulosic composition of the initial waste, the control and each fermented waste by different fungi. All lignocellulosic components were reduced when they were submitted to SSF. A small reduction was observed in control, which could be due to the effect of the sterilization processes. The SSF caused a decrease in the initial dry matter; this decrease was similar in all SSFs, from $6.9 \%$ to $14 \%$ of initial dry solid waste.

The maximum reduction of hemicellulose was calculated taking into account the loss of dry matter. A. uvarum showed the maximum reduction in BSG, EOP and VST, this being 54.2\%, $46.7 \%$ and $53 \%$ of reduction respectively. The results of hemicellulose reduction were not correlated with xylanase activities. The maximum xylanase activity was achieved by A. ibericus; however, this fungus did not achieve the maximum reduction of hemicellulose fraction.

Shinners-Carnelley et al. ${ }^{28}$ evaluated the reduction of hemicellulose of canola stubble, observing a reduction of $25 \%$ by (a)

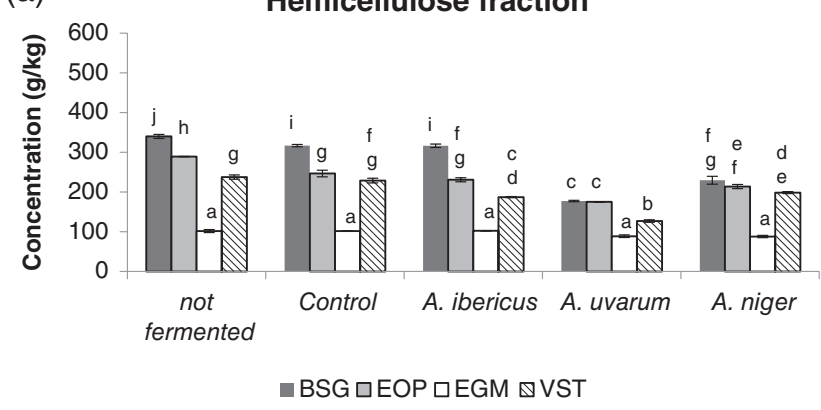

(b)
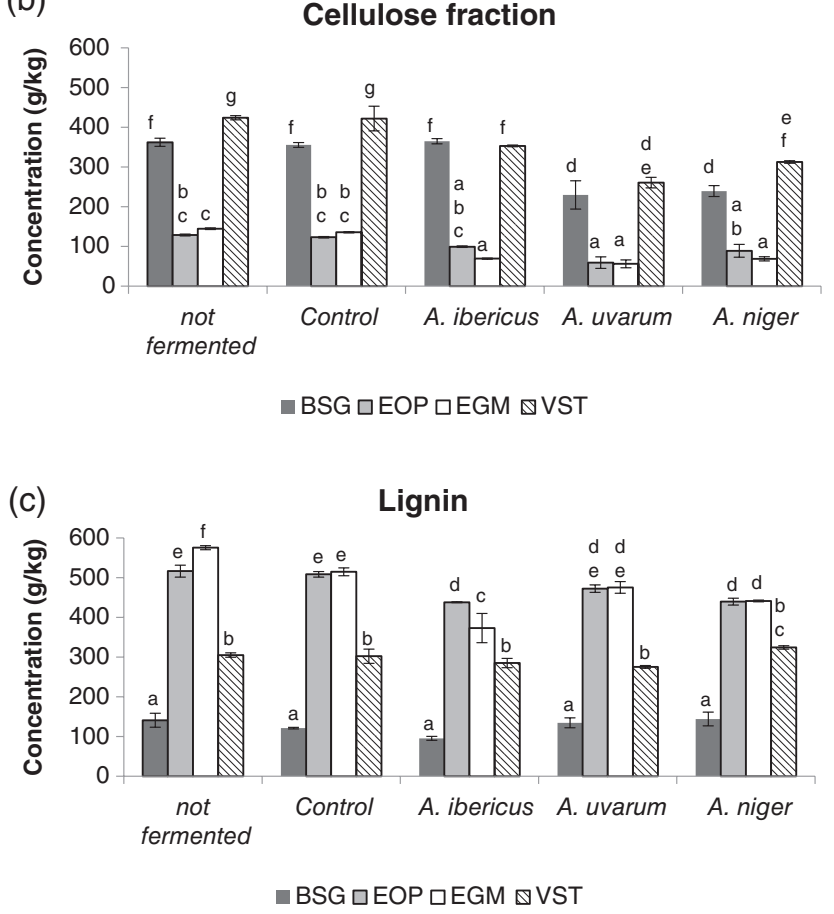

Figure 3. Lignocellulosic composition of different residues with the different fungi: (a) hemicellulose fraction, (b) cellulose fraction, (c) lignin. Letters above each bar indicate the results of Tukey's test $(P<0.05)$; values with shared letters in the same graph are not significantly different. BSG, brewers' spent grain; EOP, exhausted olive pomace; EGM, exhausted grape marc; VST, vine-shoot trimmings.

Cyathus olla in SSF. In another study, A. niger reduced the hemicellulose content $36 \%$ and Rhizopus sp. reduced $25 \%$ after 10 days of SSF of cactus pear. ${ }^{29}$ Tuyen et al. ${ }^{30}$ studied 11 fungi and observed hemicellulose reductions ranging from 7.5 to $53 \%$. The maximum xylanase production with the least hemicellulose degradation was evaluated, with BSG and EGM fermented by A.ibericus showing the best ratio of xylanase activity: reduction of hemicellulose (3.1). In this way, the fermented waste keeps the hemicellulose fraction for use as an animal feed or in the biorefinery industries.

The cellulose content was reduced in all fermentations. A. ibericus showed the least cellulose degradation in all wastes except with in EGM, which was similar in the three fungi. The best ratio of cellulase activity: reduction of cellulose was achieved by A. ibericus in BSG (4.9). The reduction of cellulose in SSF was observed in other fungi: Trametes versicolor reduced the cellulose of wheat straw $44.8 \%$ after 49 days of $\mathrm{SSF}^{30}$ and A. niger achieved a similar reduction of cellulose content $(40 \%)$ in SSF of cactus pear after 10 days. ${ }^{29}$ 

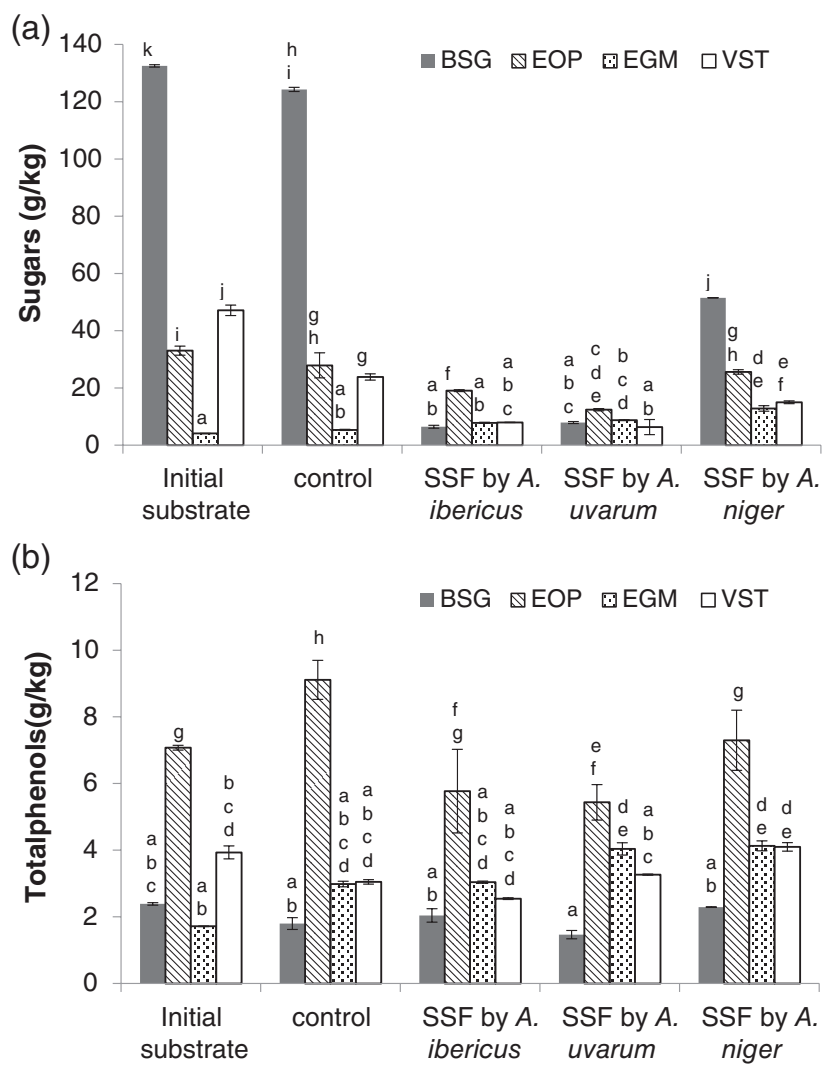

Figure 4. Content of free sugars (a) and phenolic compounds (b) in the initial substrate, control and residues after SSF with A. ibericus, A. uvarum and A. niger. Letters above each bar indicate the results of Tukey's test $(P<0.05)$; values with shared letters in the same graph are not significantly different. BSG, brewers' spent grain; EOP, exhausted olive pomace; EGM, exhausted grape marc; VST, vine-shoot trimmings.

The reduction of lignin content can improve the rumen fermentability of lignocellulosic wastes. ${ }^{30}$ Figure 3(c) shows that the content of lignin decreased after SSF. The reduction of lignin content (taking into account the loss of dry matter) was higher when A.ibericus was inoculated for all wastes. The maximum reduction of lignin was achieved in SSF of EGM (43\%), followed by SSF of BSG (40\%) after 7 days. Chen et al. ${ }^{31}$ observed in fermentation of cornstalk a decrease of lignin of $10 \%$ after 30 days. Carvalho do Santos et al. ${ }^{29}$ observed a decrease of lignin of $28 \%$ after SSF by A. niger and $18 \%$ by Rhizopus sp. Tuyen et al. ${ }^{30}$ demonstrated a high correlation between reduction of lignin and hemicellulose reduction ( $r=0.96)$. In this study, we obtained a correlation of $r=0.68$. Thus, the degradation of hemicellulose was accompanied by delignification of waste. This correlation could be due to the fungi actuating in ether and ester bonds that linked covalently the lignin and hemicellulose. Another reason could be the delignification of waste can improve the accessibility of xylanases to hemicellulose, increasing their degradation. ${ }^{30}$

\section{Variation of free sugars and phenol compounds in the extract after SSF}

The effect of fungus growth on sugars and phenolic compounds content was evaluated. Figure 4(a) shows the free sugars available in the control, initial substrate and solid wastes after SSF. The evaluation of sugars concentrations is very important because in high concentrations they can act as catabolite repressors of enzymes production. ${ }^{32}$ However, in low concentrations they can improve enzyme production. ${ }^{33}$ The low concentration of sugars can be consumed rapidly by the fungi growth at the start of fermentation, and thus they favour the fast colonization of substrate. When these sugars are consumed, the fungi should by another source of $C$ and produce carbohydrases to extract sugars from raw material. In addition, SSF has been demonstrated to be a good strategy to minimize catabolite repression. ${ }^{34}$ BSG was the waste with higher sugar content $\left(130 \mathrm{~g} \mathrm{~kg}^{-1}\right)$, followed by EOP and VST with $30 \mathrm{~g} \mathrm{~kg}^{-1}$ and $40 \mathrm{~g} \mathrm{~kg}^{-1}$ of sugars respectively. EGM showed the lowest sugar concentration, with $4 \mathrm{~g} \mathrm{~kg}^{-1}$, since all the sugars were consumed during winemaking.

The high concentration of free sugars of BSG did not inhibit enzyme production by A. uvarum and A.ibericus. However, A. niger showed a low enzyme production that could be due to the catabolite repression of free sugars. In this sense, de

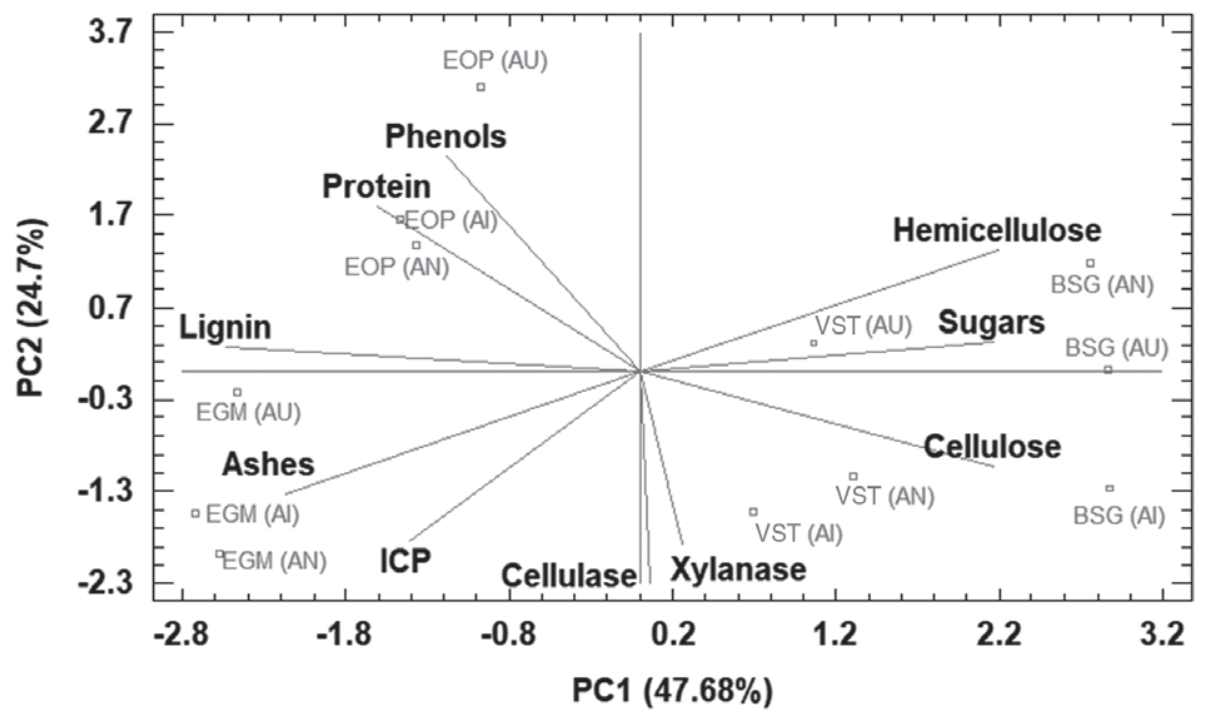

Figure 5. Principal component analysis. Biplot representation of variables and SSF experiments performed. ICP, increase content of protein; BSG, brewers' spent grain; EOP, exhausted olive pomace; EGM, exhausted grape marc; VST, vine-shoot trimmings; AU, A. uvarum; AN, A. niger; Al, A. ibericus. 
Souza et al. ${ }^{32}$ observed significant reduction of xylanase production by Aspergillus tamarii with free sugar concentrations over $100 \mathrm{~g} \mathrm{~kg}^{-1}$. In SSF by A. niger, Gokhale et al. ${ }^{33}$ observed the maximum repression with concentrations of glucose over $50 \mathrm{~g} \mathrm{~kg}^{-1}$. Low concentrations of sugars can increase enzyme production, and Gokhale et al. ${ }^{33}$ observed a positive effect of $10 \mathrm{~g} \mathrm{~kg}^{-1}$ glucose on cellulase production.

It is difficult to observe the kinetic profiles of reducing sugars generation and consumption during SSF. The fungus consumes the reducing sugars and then it produces enzymes that can hydrolyse the lignocellulosic wastes to more reducing sugars, which can be again consumed by the fungus. In general, a reduction of the concentration of free sugars was observed after SSF with the exception of EGM, in which the concentration of free sugars after SSF was similar to the control.

Figure 4(b) shows the results of total phenols determined in the initial substrate, control and the four residues after SSF. In these results, it is possible to observe that the concentration of total phenols after SSF was very similar to the values obtained in the control; no significant differences were observed $(P<0.05)$ with the exception of EOP, where it is possible to observe a clear decrease of total phenols concentration. It was expected that the phenolic compounds could decrease after SSF because the fungi have the ability to degrade phenolic compounds present in wastes. ${ }^{35}$

\section{Relationship among substrates, fungi and SSF performance}

A principal components analysis was carried out in order to assess the relationship between substrate composition, fungi used, enzymes produced and protein increase. This study allowed us to obtain a small number of lineal combinations of the 10 variables studied to explain the variability of the data. In this analysis, three components were defined that explain $87.4 \%$ of the variability of the original data. The first two principal components, PC1 and PC2, are shown in Fig. 5, accounted for $72.38 \%$ of the variability $(47.68 \%$ and $24.7 \%$ respectively). PC1 was characterized positively by high concentration of cellulose, hemicellulose and sugars, and negatively with lignin and ashes content. As can be observed, the substrates with high hemicellulose and cellulose content were positively correlated with cellulase and xylanase production and negatively correlated with lignin and ashes content. For PC2, phenols and protein were characterized positively and cellulase, xylanase and increase of protein content were characterized negatively. The negative effect of phenols content on enzyme production and in the increase of protein content is clearly visible. The principal components analysis grouped the four different substrates: BSG was characterized as a waste with high content in hemicellulose, cellulose and sugars and a low content in lignin and ashes; EOP was highly correlated with a high content of phenolic compounds and low production of cellulases, xylanases and protein; EGM was clearly characterized as a waste with high content in lignin and ashes; and VST was correlated with high production of enzymes and a low content in phenolic compounds. As far as the strain of fungus used, $A$. ibericus was highly correlated with production of enzymes and increase of protein content, except with SSF using EOP as substrate.

\section{Morphology of $A$. ibericus and structure changes on substrate during SSF}

SEM was used to observe the growth of A. ibericus on agro-food wastes. This analysis allowed characterization of the morphology of the fungus and its distribution over the solid wastes. Figure 6 compares the four materials studied before and after SSF. As can be observed, A. ibericus colonized massively and dispersedly all substrates by hyphae and conidia. In general, the fungi in SSF conditions grow on the surface of the substrate, inside the substrate and as aerial hyphae forming conidiophores and conidia. ${ }^{36}$ These regions can be observed in the micrographs. Fig. 6(B3, F2) shows clearly the formation of conidiophores in the aerial region, and huge amounts of conidia forming chains disperse and being part of the conidiophores. This type of growth was observed mainly using BSG and EGM as substrate. The surface texture of conidia showed roughness (Fig.6(B1)); this structure had previously been noted by Serra et al. ${ }^{37}$ They observed that $A$. ibericus is characterized by biseriate conidiophores and conidia with a size of 5-7 $\mu \mathrm{m}$. In all wastes, the fungus grew on their surface; the formation of hyphae in a scattered manner can be observed in Fig. 6(B3, D3, F1, H2). The hyphae also penetrated into substrates, disseminating hydrolytic enzymes (Fig. 6(B3, D3, F1, H2)).

On the other hand, the colonization of substrate by A.ibericus produced a degradation of the agro-food wastes structure. This degradation observed in the micrographs is in line with the aforementioned results showing the characterization of fermented wastes and the production of lignocellulolytic enzymes. The fungus showed an aggressive attack on the structure of VST (Fig. 6(H1)), which shows different regions (Fig. 6(G1)): vessels, ray cells and fibre cells. The fungus grew preferentially in vessels and ray cells regions. This may be because vessels provide large open spaces for hyphae growth and because ray cells contain a large amount of nutrients and a low inhibitors content. ${ }^{38}$ The degradation of structure of agro-food wastes by SSF may favour the digestibility of these wastes by animals and increase the accessibility to their nutrients. ${ }^{1}$ In this sense, the use of fermented agro-food wastes by Aspergillus species has been evaluated as feed for pigs, showing a better digestibility compared with unfermented wastes. ${ }^{39}$ To a large extent, this improvement is due to the degradation of their structure.

\section{CONCLUSION}

This study showed the potential of the barely studied strains A. ibericus and A. uvarum to increase the nutritional value of main Mediterranean agro-food wastes and to produce lignocellulolytics in the same process. The growth of fungi led to a significant increase of protein content of the four wastes studied, highlighting the increase of protein on winery wastes. In the same process, these strains produced xylanase and cellulases. A. ibericus was also the fungus that maximized the production of xylanases and cellulases, with BSG being the best substrate for enzymes production. The degradation of lignocellulosic compounds by fungi was demonstrated; this can facilitate the digestibility of wastes by animals. Moreover, the high hemicellulose and cellulose content favoured the production of lignocellulolytic enzymes, and the high phenols content limited the production of enzymes and the increase of protein. On the other hand, SEM analysis showed the degradation in the structure of wastes by the growth of $A$. ibericus and the liberation of lignocellulolytic enzymes.

Integral use of wastes was carried out without the generation of additional wastes. Thus, SSF may be an alternative technology to reuse Mediterranean agro-food and may offer two new products, namely fermented waste and an enzyme cocktail, with potential application in the food industry. 

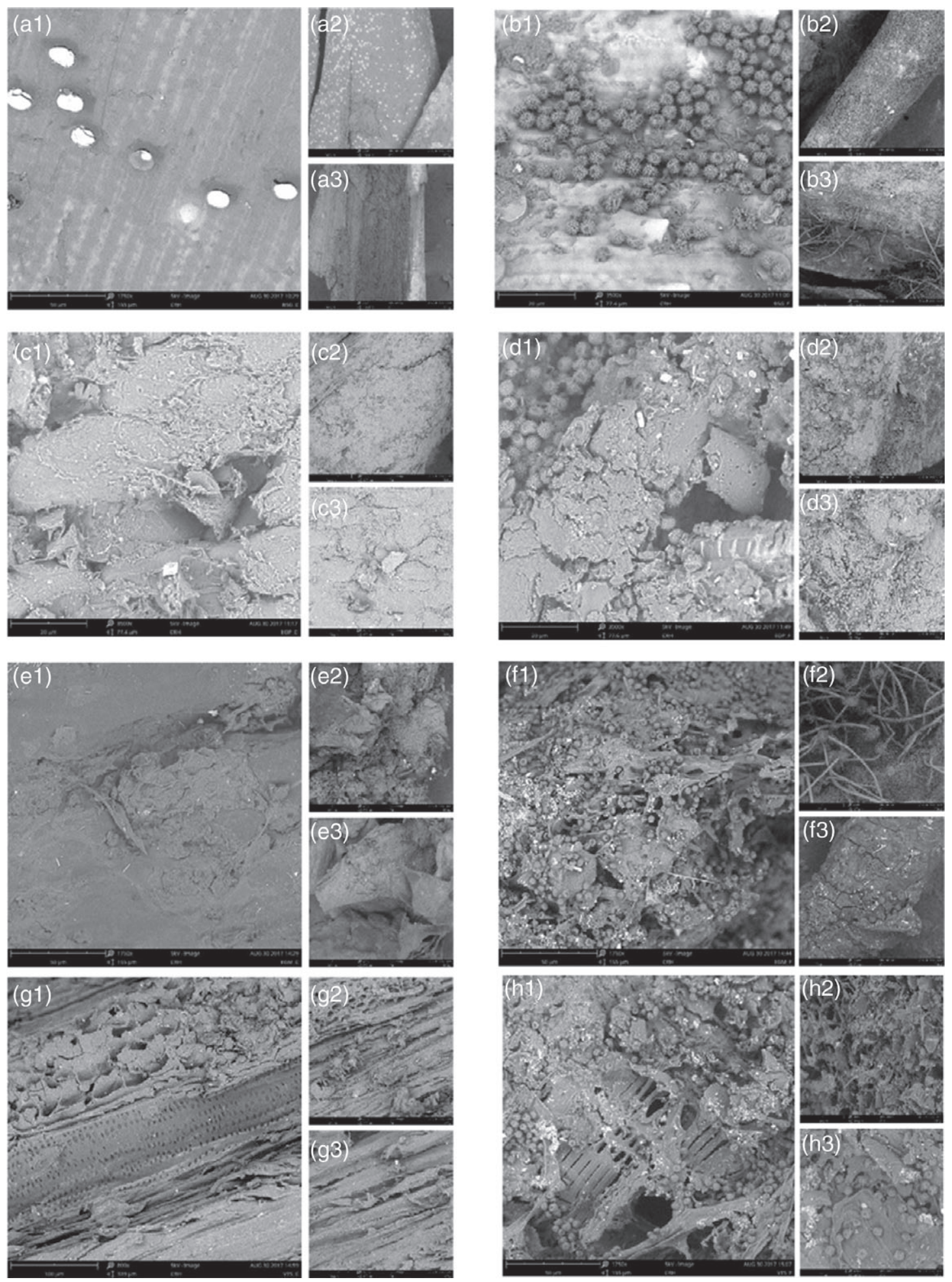

Figure 6. SEM images of unfermented and fermented wastes. (A1 - A3) Structure of unfermented BSG at different scales. (B1 - B3) View of A. ibericus growth on BSG at different scales. (C1 - C3) Structure of unfermented EOP at different scales. (D1-D3) View of A. ibericus growth on EOP at different scales. (E1 - E3) Structure of unfermented EGM at different scales. (F1-F3) View of $A$. ibericus growth on EGM at different scales. (G1-G3) Structure of unfermented VST at different scales. ( $\mathrm{H} 1-\mathrm{H} 3)$ View of $A$. ibericus growth on VST at different scales.

\section{ACKNOWLEDGEMENTS}

José Manuel Salgado was supported by grant CEB/N2020 - INV/ 01/2016 from Project 'BIOTECNORTE - Underpinning biotechnology to foster the north of Portugal bioeconomy' (NORTE-01-0145-
FEDER-000004). This study was supported by the Portuguese Foundation for Science and Technology (FCT) under the scope of the strategic funding of UID/BIO/04469/2013 unit and COMPETE 2020 (POCl-01-0145-FEDER-006684) and BioTec-Norte operation (NORTE-01-0145-FEDER-000004) funded by the European 
Regional Development Fund under the scope of Norte2020 Programa Operacional Regional do Norte.

\section{REFERENCES}

1 Ajila CM, Brar SK, Verma M, Tyagi RD, Godbout $S$ and Valéro JR, Bio-processing of agro-byproducts to animal feed. Crit Rev Biotechnol 32:382-400 (2012).

2 Molina-Alcaide E, Morales-García EY, Martín-García Al, Ben Salem H, Nefzaoui A and Sanz-Sampelayo MR, Effects of partial replacement of concentrate with feed blocks on nutrient utilization, microbial $\mathrm{N}$ flow, and milk yield and composition in goats. J Dairy Sci 93:2076-2087 (2010).

3 Salgado JM, Abrunhosa L, Venâncio A, Domínguez JM and Belo I, Screening of winery and olive mill wastes for lignocellulolytic enzyme production from Aspergillus species by solid-state fermentation. Biomass Conv Biorefin 4:201 - 209 (2014).

4 Rocha dos Santos Mathias T, Marinho Fontes Alexandre V, Cammarota MC, Moretzsohn de Mello PP and Camporese Sérvulo EF, Characterization and determination of brewer's solid wastes composition. J Inst Brew 121:400-404 (2015).

5 Pandey A, Soccol CR, Nigam P and Soccol VT, Biotechnological potential of agro-industrial residues. I: sugarcane bagasse. Bioresour Technol 74:69-80 (2000).

6 Rodríguez de Olmos A, Bru E and Garro MS, Optimization of fermentation parameters to study the behavior of selected lactic cultures on soy solid state fermentation. Int J Food Microbiol 196:16-23 (2015).

7 Valdez-González F, Gutiérrez-Dorado R, Hernández-Llamas A, García-Ulloa M, Sánchez-Magaña L, Cuevas-Rodríguez B et al., Bioprocessing of common beans in diets for tilapia: in vivo digestibility and antinutritional factors. J Sci Food Agric 97:4087-4093 (2017).

8 Gélinas $P$ and Barrette J, Protein enrichment of potato processing waste through yeast fermentation. Bioresour Technol 98:1138-1143 (2007).

9 Han J, Solid-state fermentation of cornmeal with the basidiomycete Hericium erinaceum for degrading starch and upgrading nutritional value. Int J Food Microbiol 80:61 -66 (2003).

10 Jin B, Zepf F, Bai Z, Gao B and Zhu N, A biotech-systematic approach to select fungi for bioconversion of winery biomass wastes to nutrient-rich feed. Proc Saf Environ 103:60-68 (2016).

11 Graminha EBN, Gonçalves AZL, Pirota RDPB, Balsalobre MAA, Da Silva $\mathrm{R}$ and Gomes $\mathrm{E}$, Enzyme production by solid-state fermentation: application to animal nutrition. Anim Feed Sci Technol 144:1-22 (2008).

12 Iconomou D, Kandylis K, Israilides $C$ and Nikokyris $\mathrm{P}$, Protein enhancement of sugar beet pulp by fermentation and estimation of protein degradability in the rumen of sheep. Small Ruminant Res 27:55-61 (1998).

13 Perrone G, Susca A, Cozzi G, Ehrlich K, Varga J, Frisvad JC et al., Biodiversity of Aspergillus species in some important agricultural products. Stud Mycol 59:53-66 (2007).

14 Salgado JM, Abrunhosa L, Venâncio A, Domínguez JM and Belo I, Integrated use of residues from olive mill and winery for lipase production by solid state fermentation with Aspergillus sp. Appl Biochem Biotechnol 172:1832-1845 (2014).

15 Annamalai N, Rajeswari MV, Thavasi R, Vijayalakshmi S and Balasubramanian T, Optimization, purification and characterization of novel thermostable, haloalkaline, solvent stable protease from Bacillus halodurans CAS6 using marine shellfish wastes: a potential additive for detergent and antioxidant synthesis. Bioprocess Biosyst Eng 36:873-883 (2013).

16 Miller GL, Use of dinitrosalicylic acid reagent for determination of reducing sugar. Anal Chem 31:426-428 (1959).

17 APHA, Standard Methods for the Examination of Water and Wastewater, 16th edn. American Public Health Association, Washington, DC (1985).

18 Jones DB, Factors for Converting Percentages of Nitrogen in Foods and Feeds into Percentages of Proteins. Circular No. 183. United States Department of Agriculture, Washington, DC (1941).

19 Leite P, Salgado JM, Venâncio A, Domínguez JM and Belo I, Ultrasounds pretreatment of olive pomace to improve xylanase and cellulase production by solid-state fermentation. Bioresour Technol 214:737-746 (2016).
20 Salgado JM, Abrunhosa L, Venâncio A, Domínguez JM and Belo I, Enhancing the bioconversion of winery and olive mill waste mixtures into lignocellulolytic enzymes and animal feed by Aspergillus uvarum using a packed-bed bioreactor. J Agric Food Chem 63:9306-9314 (2015).

21 Hamdi HS, Production of mini-food by Aspergillus niger, Rhizopus oryzae and Saccharomyces cerevisiae using orange peels. Rom Biotechnol Lett 18:7929-7946 (2013).

22 Ahmed S, Mustafa G, Arshad M and Rajoka MI, Fungal biomass protein production from Trichoderma harzianum using rice polishing. BioMed Res Int 2017:9, Article ID 6232793 (2017).

23 Silva Canedo M, Gomes de Paula F, Alves da Silva F and Vendruscolo F, Protein enrichment of brewery spent grain from Rhizopus oligosporus by solid-state fermentation. Bioprocess Biosyst Eng 39:1105-1113 (2016).

24 Brozzoli V, Bartocci S, Terramoccia S, Contò G, Federici F, D'Annibale A et al., Stoned olive pomace fermentation with Pleurotus species and its evaluation as a possible animal feed. Enzyme Microb Technol 46:223-228 (2010).

25 Vijayakumar M, Joseph I and Raj RP, Efficacy of a fungal fermented product as fishmeal replacement in the diet of Penaeus monodon Fabricius post-larvae. Indian J Fish 56:115-121 (2009).

$26 \mathrm{Sim}$ TS and Oh JCS, 1990. Spent brewery grains as substrate for the production of cellulases by Trichoderma reesei QM9414. J Ind Microbiol 5:153-158 (1990).

27 Chmelova D, Ondrejovic M, Ondas V and Sturdik E, Influence of cultivation conditions on production of lignocellulolytic enzymes by Ceriporiopsis subvermispora. Biologia 66:748-754 (2011).

28 Shinners-Carnelley TC, Szpacenko A, Tewari JP and Palcic MM, Enzymatic activity of Cyathus olla during solid state fermentation of canola roots. Phytoprotection 83:31-40 (2002).

29 Carvalho do Santos T, Alves Diniz G, de Brito AR, Vieira Pires AJ and Franco $M$, Effect of solid state fermentation on nutritional content and evaluation of degradability in cactus pear. Rev Caatinga 28:248-254 (2015).

30 Tuyen VD, Cone JW, Baars JJP, Sonnenberg ASM and Hendriks WH, Fungal strain and incubation period affect chemical composition and nutrient availability of wheat straw for rumen fermentation. Bioresour Technol 111:336-342 (2012).

31 Chen Y, Fan H and Meng F, Pleurotus ostreatus decreases cornstalk lignin content, potentially improving its suitability for animal feed. J Sci Food Agric 97:1592-1598 (2017).

32 Farani de Souza D, Giatti Marques de Souza C and Peralta RM, Effect of easily metabolizable sugars in the production of xylanase by Aspergillus tamarii in solid-state fermentation. Process Biochem 36:835-838 (2001).

33 Gokhale DV, Patil SG and Bastawde KB, Optimization of cellulase production by Aspergillus niger NCIM 1207. Appl Biochem Biotechnol 30:99-109 (1991).

34 Gessesse A and Mamo G, High-level xylanase production by an alkaliphilic Bacillus sp. by using solid-state fermentation. Enzyme Microb Technol 25:68-72 (1999).

35 Salgado JM, Abrunhosa L, Venâncio A, Domínguez JM and Belo I, Combined bioremediation and enzyme production by Aspergillus $\mathrm{sp}$. in olive mill and winery wastewaters. Int Biodeterior Biodegrad 110:16-23 (2016)

36 Mitchell DA, Berovi M, Nopharatana M and Krieger N, The bioreactor step of SSF: a complex interaction of phenomena, in Solid-State Fermentation Bioreactors. Fundamentals of Design and Operation, ed. by Mitchell DA, Krieger N and Berovič M. Springer-Verlag, Berlin, pp. 13-32 (2006).

37 Serra R, Cabañes FJ, Perrone G, Castellá G, Venâncio A, Mulè G et al., Aspergillus ibericus: a new species of section Nigri isolated from grapes. Mycologia 98:295-306 (2006).

38 Liew CY, Husaini A, Hussain H, Muid S, Liew KC and Roslan HA, Lignin biodegradation and ligninolytic enzyme studies during biopulping of Acacia mangium wood chips by tropical white rot fungi. World J Microb Biotechnol 27:1457-1468 (2011).

39 Shi C, He J, Wang J, Yu J, Yu B, Mao X et al., Effects of Aspergillus niger fermented rapeseed meal on nutrient digestibility, growth performance and serum parameters in growing pigs. Anim Sci J 87:557-563 (2016). 